\title{
CXCR4 wt Allele
}

National Cancer Institute

\section{Source}

National Cancer Institute. CXCR4 wt Allele. NCI Thesaurus. Code C51336.

Human CXCR4 wild-type allele is located within 2 q21 and is approximately $4 \mathrm{~kb}$ in length. This allele, which encodes C-X-C chemokine receptor type 4 protein, plays a role in the mediation of leukocyte and hematopoietic cell migration and may be involved in central nervous system development. Mutations in this gene have been associated with WHIM (warts, hypogammaglobulinemia, infections, and myelokathexis) syndrome. 